\title{
Software de autoria colaborativa de materiais educacionais para a TV digital
}

\author{
Marco Antônio Sandini Trentin ${ }^{1}$ \\ Adriano Canabarro Teixeira ${ }^{1}$ \\ Cássio Feldkircher ${ }^{1,2}$
}

\begin{abstract}
Resumo: O presente artigo tem como objetivo descrever o processo de desenvolvimento de um software de autoria colaborativa que proporcione aos professores, alunos e demais seres sociais envolvidos nos processos de ensino-aprendizagem escolares a possibilidade de produção de materiais educativos hipermídia para a TV digital. Por meio da descrição dos aspectos técnicos e educacionais, os quais partem da relação interdisciplinar entre as áreas da informática, comunicação e educação, torna-se possível delinear o progresso atual da pesquisa em torno do desenvolvimento deste software, denominado "Guri".
\end{abstract}

Palavras-chave: Aplicações interativas. Informática na educação. TV Digital.

\begin{abstract}
The present article aims to describe the development process of a collaborative authorship software, which provides to teachers, students and other social beings involved in the school teaching-learning process the possibility of hypermedia educational content production to the Digital TV. By describing the technical and educational aspects, which initiate at the interdisciplinary relation among the Computing, Communication and Education areas, it becomes possible to delineate the present research progress around the development of this software, named "Guri".
\end{abstract}

Keywords: Computing in education. Digital TV. Interactive applications.

\section{Introdução}

Por meio da imbricação dos artefatos técnicos de comunicação interativa com as questões culturais emergentes na sociedade contemporânea, configura-se o fenômeno da cibercultura. Tal contexto sociocultural é caracterizado pela inédita liberação dos polos de emissão, onde os diferentes atores sociais, anteriormente repreendidos pela unidirecionalidade dos mass media, encontram na convergência da informática com as telecomunicações as linguagens comunicacionais necessárias para a configuração de processos culturais baseados no protagonismo criativo [1].

Assim, para que o cidadão pertença de fato à cibercultura, ele deve ter a capacidade de apropriar-se criticamente das potencialidades desses artefatos tecnológicos comunicativos contemporâneos, as Tecnologias Digitais de Rede (TDRs), participando dos processos culturais, econômicos, políticos, entre outros.

Nesse contexto, julga-se que a TV digital em sua convergência com as TDRs pode representar o desencadeamento de novas possibilidades de inclusão social/digital e educativa dos cidadãos. A televisão é uma mídia a qual a ampla maioria dos brasileiros tem acesso, índice que totaliza 95,7\%, segundo dados da Pesquisa Nacional por Amostra de Domicílios 2009 [2, p. 79]. Ainda, o decreto nº 5.820 de 2006, que define a instituição do Sistema Brasileiro de TV Digital Terrestre (SBTVD-T), pontua o período de transição do sistema televisivo analógico para o sistema de televisão digital em dez anos, contados a partir da data de publicação do decreto [3].

\footnotetext{
${ }^{1}$ Curso de Ciência da Computação, UPF, Campus 1 - BR 285 - Passo Fundo (RS) - Brasil

\{trentin, Teixeira, 97538 @upf.br\}

${ }^{2}$ Bolsista PIBIC - UPF
}

http://dx.doi.org/10.5335/rbca.2012.2115

Revista Brasileira de Computação Aplicada (ISSN 2176-6649), Passo Fundo, v. 4, n. 1, p. 92-101, mar. 201292 
Portanto, supondo-se que após 2016 a totalidade dos brasileiros terão acesso ao sinal televisivo digital por meio da aquisição de um Set-Top Box (STB)[1] externo ou já integrado a aparelhos de televisão, haverá um grande potencial para processos de inclusão social/digital via acesso a aplicações interativas na TV digital.

Entretanto, para que essa inclusão ocorra, julga-se que a escola possua um papel central nos movimentos de apropriação desse novo meio de comunicação. Porém, é importante frisar que tal fato somente se concretizará na medida em que este artefato tecnológico operar, por meio das suas características interativas, uma (re)configuração nos delineadores pedagógicos que regem os processos educativos tradicionais, ainda arraigados a uma perspectiva marcada pela transmissão linear de informações.

Dessa forma, o presente artigo visa descrever o desenvolvimento de um software de autoria colaborativa de materiais educativos hipermídia voltados para a TV digital, denominado "Guri". Por meio desse software, pretende-se possibilitar aos sujeitos envolvidos no processo educativo um ambiente digital que potencialize o desenvolvimento de atividades didático-pedagógicas que considerem a coparticipação no ato de conhecimento como elemento fundamental do ensino-aprendizagem.

\section{TV digital: apropriação da interatividade no contexto educacional}

O processo de digitalização da televisão no Brasil, através da criação e implantação do SBTVD-T, configura-se como um aspecto das transformações tecno-culturais que subjazem a sociedade contemporânea. Assim, a TV digital pode ser um elemento estratégico para a sociedade brasileira no que se refere à apropriação da linguagem digital interativa e das suas possibilidades em larga escala nas mais diversas situações culturaiseducativas, atuando como uma fomentadora da inclusão digital/social [3].

Ao imbricar-se com as TDRs, as quais podem ser compreendidas "[...] como os ambientes hipermidiais ${ }^{2}$ de comunicação interativa [...] que surgem com o advento do ciberespaço e que permitem o estabelecimento de processos de autoria colaborativa e protagonismo de cada nó pertencente a uma determinada rede [...]” [4, p. 111], as características e possibilidades da televisão alteram-se substancialmente. De uma mídia que possibilitava processos comunicativos entre emissores e receptores baseados no paradigma de distribuição massiva e unidirecional de informações, tem-se agora um meio de comunicação que potencialmente contém o patamar da interatividade. Portanto, a interatividade da TV digital representa o principal elemento de ruptura entre o meio analógico/unidirecional e o digital/interativo.

Nesse contexto dos subsistemas que compõem o padrão do SBTVD-T, ${ }^{3}$ tornam-se importante para o desenvolvimento de aplicações interativas na TV digital: a) o middleware Ginga, camada de software presente no STB que permite interpretar as aplicações para a linguagem da plataforma de hardware em que residem; b) canal de interatividade, que é uma infraestrutura que possibilita a comunicação das aplicações interativas rodando no STB com servidores de aplicações dos provedores de conteúdo. No capítulo 3 questões técnicas relacionadas a esses dois subsistemas serão detalhadas.

A questão da interatividade na TV digital é um quesito importante a ser analisado na medida em que permite, entre outros, a apropriação do potencial teórico e prático deste conceito como fomentador de novas práticas educativas. Fundamentando-se na ideia de um processo de ensino-aprendizagem intrinsecamente dialógico entre professores, alunos e demais seres sociais potencialmente presentes na rede (FREIRE, 1983), o "fator interatividade" na TV digital torna-se uma característica técnico-comunicativa potencializadora da instauração de uma práxis pedagógica voltada para a autoria colaborativa, tendo a cooperação e a coparticipação na construção de coletividades inteligentes de apropriação/construção de conhecimentos no ciberespaço como conceitos norteadores [5, p. 28].

Assim, além das questões inerentemente tecnológicas envolvidas na implantação do SBTVD-T, uma questão fundamental para que os sujeitos se apropriem de maneira interativa e autoral dos conteúdos da TV digital refere-se à inclusão social/digital por intermédio de processos educativos. Para que isso ocorra é

\footnotetext{
${ }^{2} \mathrm{O}$ conceito de hipermídia pode ser compreendido nos seguintes termos: “[...] uma forma 'tridimensional' combinatória, permutacional e interativa de multimídia, onde textos, sons e imagens (estáticas ou em movimento) estão ligados entre si por elos probabilísticos e móveis, que podem ser configurados pelos receptores de diferentes maneiras, de modo a compor obras instáveis em quantidades infinitas" (MACHADO apud [6, p. 149]).

${ }^{3}$ Os subsistemas que compõem o padrão brasileiro de TV digital terrestre são: transmissão e recepção, codificação de sinais fonte, camada de transporte, middleware, canal de interatividade, terminal de acesso [7].
}

Revista Brasileira de Computação Aplicada (ISSN 2176-6649), Passo Fundo, v. 4, n. 1, p. 92-101, mar. 201293 
necessário que a ação educativa mediada por essa tecnologia seja ressignificada de acordo com as características contidas na gênese da TV digital enquanto meio de comunicação.

Em virtude disso, ressalta-se que somente o fato de disponibilizar a TV digital no ambiente educacional não significará um processo "automático" de inclusão digital, tampouco de potencialização da práxis pedagógica. Enquanto a utilização das TDRs ocorrer exclusivamente numa perspectiva de recepção de informações, de passividade perante as redes sociotécnicas que se instauram, tanto os movimentos de inclusão digital quanto de ressignificação dos processos de ensino-aprendizagem estarão sob a égide de uma lógica oposta à da interatividade, elemento central dos processos comunicativos no ciberespaço [8, p. 29-31].

Nesse sentido, as aplicações educativas produzidas para a TV digital não devem se constituir enquanto artefatos tecnológicos imbuídos do padrão de ensino bancário, mecânico e verbalista, tal como caracterizado por Freire [10, p. 57]. Devem, sobretudo, servir como um recurso de promoção da autoração, da comunicação/diálogo e da necessária coparticipação dos sujeitos no ato de apreensão do objeto de conhecimento [9, p. 65-67], por meio da construção de um conteúdo hipermidial educativo. É nesse sentido que a interatividade se torna um conceito fundamental para a investigação das potencialidades da TV digital na educação.

Em síntese, pode-se afirmar que o conceito de interatividade é responsável por exprimir a superação dos paradigmas tradicionais da comunicação de massa que moldaram a lógica de produção televisiva até então, através da

[...] disponibilização consciente de um mais comunicacional de modo expressivamente complexo, e, ao mesmo tempo, atentando para as interações existentes e promovendo mais e melhores interações - seja entre usuário e tecnologias comunicacionais (hipertextuais ou não), seja nas relações (presenciais ou virtuais) entre seres humanos [11, p. 155].

Essa predisposição para "mais comunicacional", "mais interação", ou para uma "hiperinteração", é pormenorizadamente descrita por meio dos "binômios da interatividade", tal como propostos por Silva [6, p. 100-155]. Assim, o binômio da participação-intervenção diz respeito às mudanças efetuadas no que se refere ao papel atribuído aos componentes de um processo de comunicação: o leitor possui a capacidade de participar e de intervir no modo como o processo comunicativo está sendo conduzido; já o escritor não emite tão somente uma mensagem fechada, mas propõe um conjunto de possíveis caminhos por onde o leitor poderá construir seus sentidos; por fim, a própria mensagem muda de natureza, tornando-se aberta à mudança a partir da participaçãointervenção do leitor na sua composição/modificação.

Por meio do binômio da bidirecionalidade-hibridação afirma-se que somente existe comunicação interativa "[...] a partir do momento em que não há mais nem emissor nem receptor e, a partir do momento que todo emissor é potencialmente um receptor e todo receptor é potencialmente um emissor” [6, p. 112]. Pode-se dizer que nesse contexto ocorre uma hibridização entre os papéis existentes no ato comunicativo, fundindo em um mesmo personagem as funções, sempre móveis e dinâmicas, de emissor e receptor. Por fim, o binômio potencialidade-permutabilidade expressa a capacidade de acessar de forma não linear as informações de um conteúdo interativo através de uma rede de nós e hiperlinks, a partir da ação/intenção do sujeito-autor. Assim, acaba-se por permitir não "[...] só o armazenamento de grande quantidade de informação, mas também ampla liberdade para combiná-las (permutabilidade) e produzir narrativas possíveis (potencialidade)” [6, p. 131].

Desse modo, enquanto meio de comunicação contemporâneo, a TV digital, uma vez presente no processo educativo, pode promover, através da sua característica interativa, a autoria colaborativa de conteúdos digitais hipermídia. Constitui, assim, uma ferramenta tecnológica que potencializa processos de ensino-aprendizagem baseados na comunicação/diálogo, ou seja, situações de apropriação/construção coparticipada dos objetos de conhecimento pelos sujeitos interlocutores hibridizados (educadores-educandos e educandos-educadores), através da (re)significação dos significados desses objetos, tal como são expressos na cultura produzida historicamente pela humanidade, e que serão, por fim, representados por meio de uma malha hipermídia [9, p. $69 ; 10$, p. 62-68].

Com base nessas reflexões, é possível relatar que as questões sobre conteúdos interativos educacionais para TV digital tornam-se centrais para a apropriação pedagógica desse meio de comunicação. Esses conteúdos específicos à educação são necessários para estimular a apropriação da TV digital na escola por meio de processos interativo-dialógicos de ensino-aprendizagem. Entretanto, por ser um meio de comunicação novo, 
pesquisas sobre conteúdos educativos para a TV digital devem ser fomentadas, sob o risco de subutilização da tecnologia.

Portanto, o desenvolvimento de softwares que permitam a autoria colaborativa, imbuindo-se da característica interativa intrínseca à TV digital para a criação de conteúdos hipermidiais, torna-se uma possibilidade para a potencialização de processos educativos dialógicos e, consequentemente, de inclusão digital. Para isso, visando superar o modelo educacional moldado pelo mero consumo de conteúdos pré-formatados, softwares que intencionem a autoria colaborativa devem ser desenvolvidos possuindo como norteador pedagógico a necessária coparticipação dos alunos, professores e demais seres sociais no ato de conhecimento.

A partir dessa discussão sobre os potenciais pedagógicos envolvidos na apropriação educacional da TV digital, será relatado no capítulo subsequente o desenvolvimento de um software de autoria colaborativa para a produção de materiais educacionais hipermídia, denominado "Guri”.

\section{Descrição técnica do software de autoria colaborativa Guri}

O software de autoria colaborativa de materiais educacionais hipermídia para a TV digital, denominado "Guri", está sendo desenvolvido por meio de uma parceria público-privada entre a Universidade de Passo Fundo, a Universidade Federal do Rio Grande do Sul e a microempresa Infoeduca. ${ }^{5}$

Compreende-se por "software de autoria colaborativa" uma classe de programas computacionais para autoria de hipermídia, isto é, aplicações que permitem ao usuário não apenas ser o "leitor" de um documento, mas também ser um "escritor", criando seus próprios trabalhos para publicação ou aplicação em ambientes hipermidiais [12, p. 57]. Ainda, os "materiais educacionais hipermídia" podem ser entendidos enquanto entidades digitais com diversos formatos midiáticos dispostos em arquitetura hipertextual, e que possam ser (re)utilizadas ou referenciadas durante o processo de ensino-aprendizagem suportado por tecnologias, possuindo características baseadas nos binômios da interatividade [6, p. 100-101].

Em um nível mais baixo de abstração, a malha hipermídia a ser construída por meio do software Guri estará disposta num contexto voltado para um público escolar específico, o do ensino fundamental. Nesses termos, o objetivo principal é que os alunos possam desenvolver uma malha hipermídia tendo como mote a criação de um "micromundo" temático conectado a uma ideia-conceito específica: ao do programa infantojuvenil televisivo "Mundo da Leitura,"6 criado e produzido na Universidade de Passo Fundo e que, atualmente, é transmitido nacionalmente pelo canal Futura."

A partir desse micromundo inicial "em branco" conectado ao conceito do Mundo da Leitura, os alunos em processos de autoria colaborativa com seus pares, professores e demais seres sociais, poderão conectar à malha hipermidial diversos itens de mídia (personagens, objetos, textos, vídeos, sons), formas de comunicação online (chat), TDRs (RSS, Twitter, Wikipédia) e formas de gerenciamento das decisões do grupo (votações, fóruns de discussão). Esses itens, portanto, visam formar uma malha hipermídia que representa e potencializa processos de ensino-aprendizagem dialógicos e interativos de alunos e professores do ensino fundamental.

Atualmente, a tecnologia que possibilita o desenvolvimento de tal classe de sistema computacional educativo para a TV digital, segundo os padrões do SBTVD-T, é o middleware Ginga, que constitui-se como uma camada de software que abstrai o hardware do STB, e sob a qual são estruturadas as aplicações interativas [7, p. 28]. Vale destacar que o middleware Ginga é composto por dois subsistemas principais interligados, denominados de Ginga-J (para aplicações procedurais Java) e Ginga-NCL (para aplicações declarativas NCL Nested Context Language, em conjunto com a linguagem de programação imperativa Lua). ${ }^{8}$ Nesse sentido, o

\footnotetext{
${ }^{4}$ Mais informações no site do projeto: http://guri.upf.br/

${ }^{5}$ Os estudos derivados do presente artigo estão conectados ao projeto de pesquisa "Guri - Software de Autoria Colaborativa de materiais educacionais hipermídia para a TV Digital", financiado pelo Conselho Nacional de Desenvolvimento Científico e Tecnológico (CNPq) através do Edital MCT/SETEC/CNPq nº. 67/2008 - RHAE - Pesquisador na empresa.

${ }^{6}$ No que se refere ao programa Mundo da Leitura, frisa-se que o mesmo tem por objetivo servir "[...] de incentivo para o desenvolvimento da criatividade, do raciocínio lógico e, principalmente, para a criação do hábito da leitura entre as crianças", utilizando-se para alcançar tais requisitos uma apresentação conectada a formas lúdicas e dinâmicas, bem como “[...] as diversas linguagens [...] - manipulação de bonecos, leitura e encenação de textos infantis, artes gráficas, música, entre outros [...]". Mais informações em: http://mundodaleitura.upf.br/programa/mundodaleitura/index.html

${ }^{7}$ Acesso em: http://www.futura.org.br/

${ }^{8}$ Mais informações em: http://www.ginga.org.br/index.html.
} 
conjunto de máquinas de execução das linguagens oferecidas para esse middleware, as bibliotecas de funções existentes e constantemente atualizadas, bem como as demais aplicações, frameworks e ambientes de autoria e programação, provêm um conjunto de artefatos tecnológicos que permitem diversas possibilidades no desenvolvimento de aplicações interativas voltadas para a TV digital.

No que se refere às questões de engenharia de software, a aplicação interativa Guri foi desenvolvida através do processo de prototipação incremental. Um protótipo inicial do software foi desenvolvido com base em um subconjunto mínimo de requisitos (funcionalidades) e, então, a cada iteração do processo de desenvolvimento foram adicionadas novas funcionalidades a esse subconjunto. O protótipo é, assim, incrementado para abarcar essas adições. ${ }^{9}$

A seguir são descritas as funcionalidades do protótipo da iteração atual, ainda em desenvolvimento, na qual o software Guri permite que um conjunto de usuários devidamente cadastrados efetive a criação e exibição de apresentações de slides multimídia na TV digital.

O software Guri é dividido em dois módulos principais: o cliente, uma aplicação interativa desenvolvida em Ginga-NCLua que executa sobre a TV digital, e o servidor, um WebService e interface web, desenvolvido em Java, que executa em um servidor. De maneira mais específica, para o desenvolvimento do módulo cliente foram utilizados, em um ambiente linux (Ubuntu 10.10): a) o editor de textos vim para editar os códigos em Lua e NCL; b) o Set-Top Box Virtual Ginga (versão 0.12.1 atualmente), que executa sobre o VMWare Player, e que tem como função testar as aplicações escritas em Lua e NCL para a TV digital, simulando o ambiente onde, posteriormente, o software será executado. Já para o desenvolvimento do módulo servidor, o qual faz uso das tecnologias Java 6, GlassFish 3.1 (Open Source Edition) e PostgreSQL 8.5, foi utilizado, em ambiente Windows, a IDE Netbeans (versão 6.9). A seguir são apresentados trechos de código nas linguagens NCL e Lua, visando demonstrar, no documento main.ncl, as mídias da tela inicial do software e o funcionamento do botão que direciona a tela principal, bem como, no documento main.lua, a rotina que responde aos eventos gerados pelo usuário e o formatador NCL.

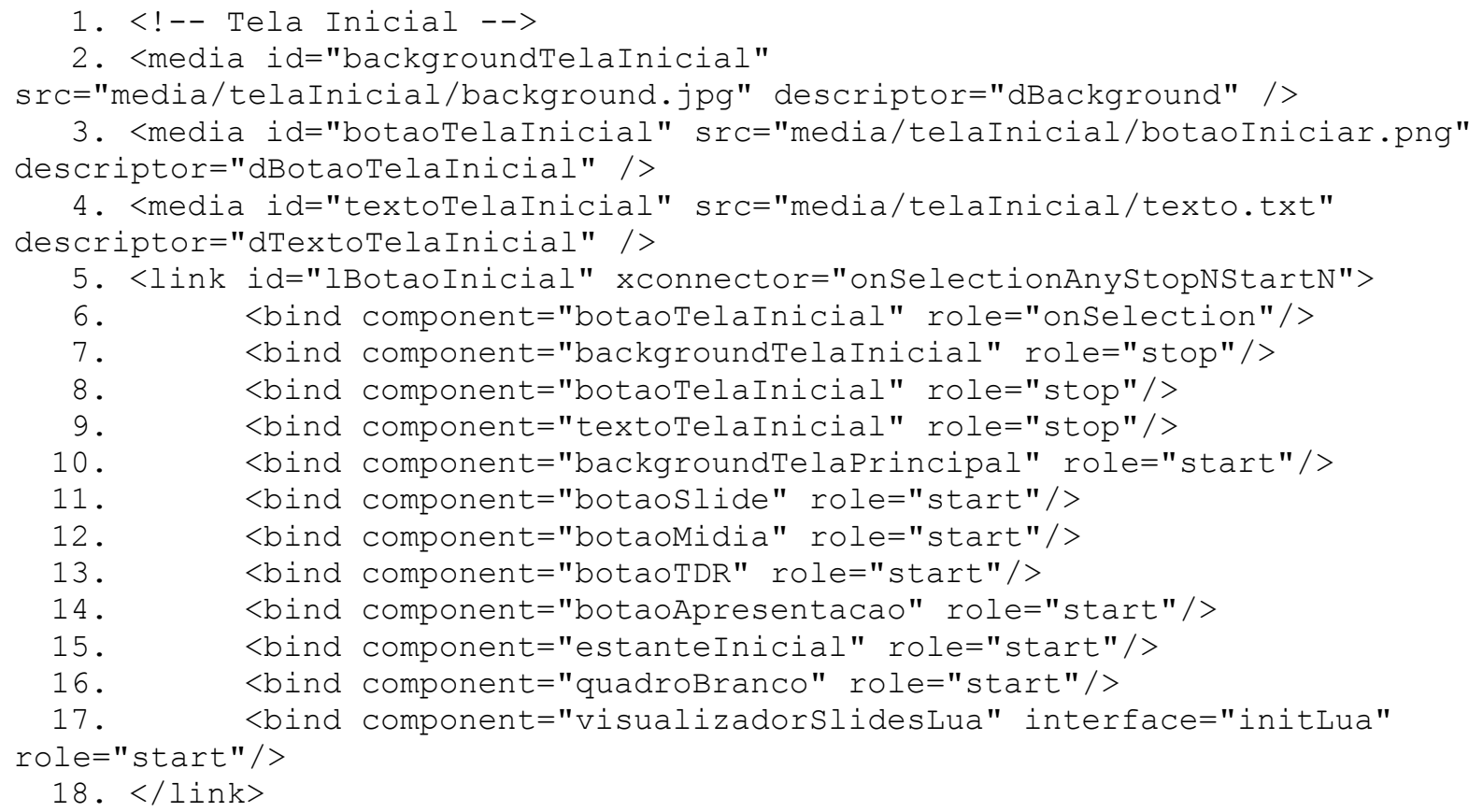

\footnotetext{
${ }^{9}$ O desenvolvimento do software Guri seguiu os princípios propostos pelo Manifesto Ágil (disponível em: http://agilemanifesto.org) e, de forma mais específica, a metodologia XP (eXtreme Programming) [13].
} 


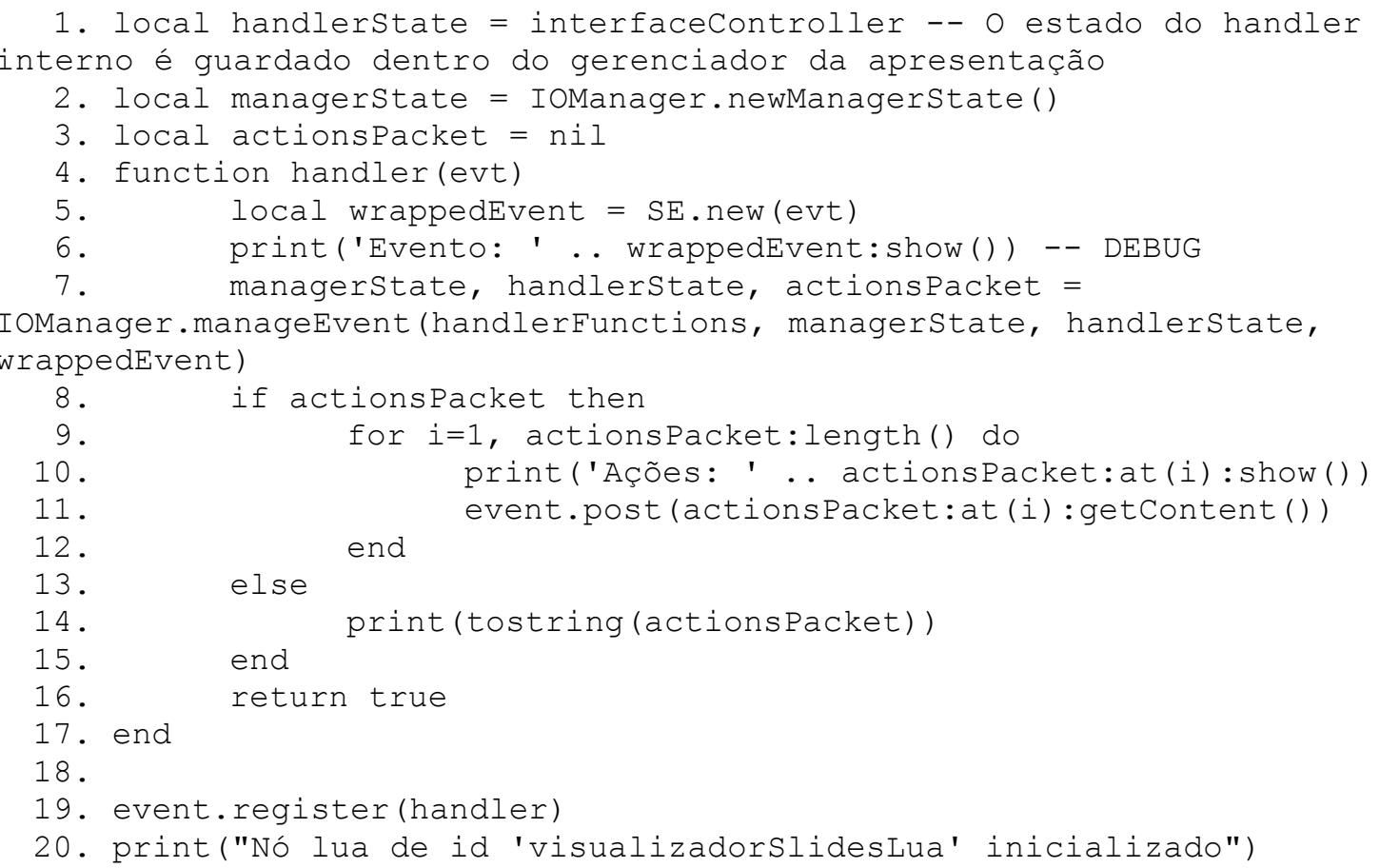

O módulo cliente tem como objetivo oferecer ao usuário uma interface que possibilite a exibição, edição e gerenciamento das suas apresentações de slides. Isso permitirá aos alunos que disponham de um STB e uma conexão com a internet desenvolver apresentações multimídias fora do laboratório de informática da escola, sem a necessidade de um computador.

A tela inicial do protótipo do cliente é composta do campo de usuário e de senha, a fim de autenticar o usuário e permitir acesso às suas apresentações para exibição, edição e gerenciamento. Após a autenticação na tela de login, o usuário é redirecionado para a tela de seleção, onde lhe é possível escolher entre criar uma nova apresentação, ou editar uma de suas apresentações já existentes. A tela de edição (Fig. 1) é a principal do módulo cliente do software Guri. Permite a edição de uma apresentação de slides e sua exibição. O menu principal (item 1) do software é composto de cinco opções: "Composição de slides" (subitem 1a), "Galerias de mídias" (subitem 1b), "Tecnologias digitais de rede" (subitem 1c), "Iniciar apresentação de slides" (subitem 1d) e "Salvar apresentação" (subitem 1e). Os três primeiros itens, quando selecionados, alteram as operações no submenu (item 2) e deslocam o foco para seleção de um dos seus desdobramentos.

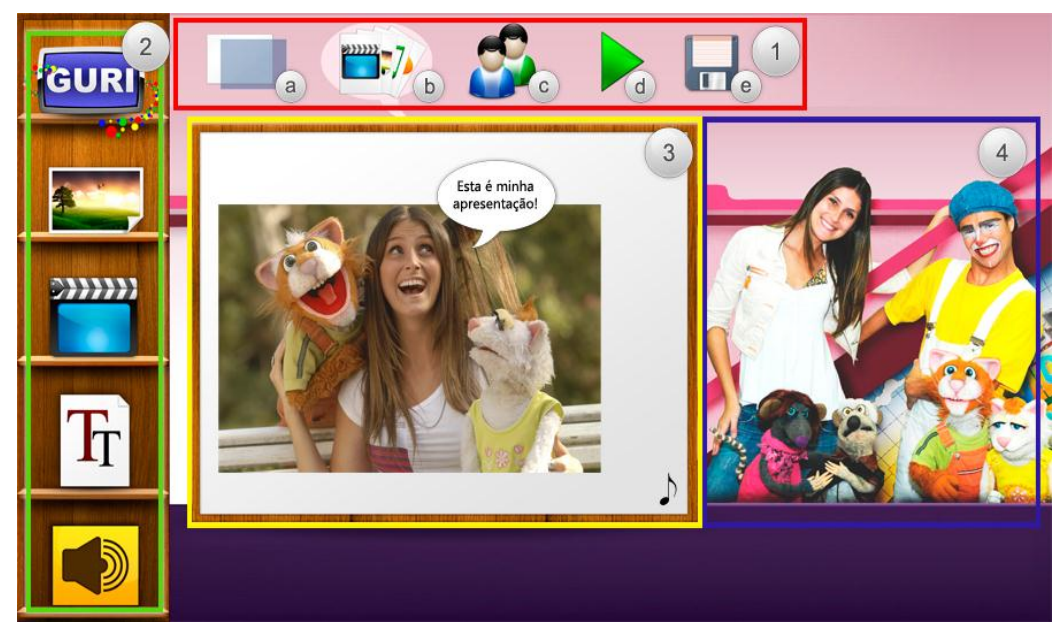

Figura 1: Tela de edição do software de autoria colaborativa Guri, com o item Galerias de mídia selecionado 
A opção "Composição de slides" agrega as ações executadas sobre a sequência de slides em si (não os elementos de mídia contidos nos slides), sendo: adição de um novo slide em branco após o atual, exclusão do slide atualmente em foco e a troca da posição na sequência entre dois slides distintos. A opção "Galerias de mídia" oferece no submenu a seleção entre as galerias de textos, imagens, vídeos e áudios. Ao se selecionar uma das galerias, a tela de edição é substituída pela tela da galeria específica, onde um conjunto de mídias é apresentado para seleção na forma de ícones. As imagens e textos são representados por eles mesmos; os vídeos, por um frame capturado; os áudios, por um rótulo. Quando uma mídia é selecionada, é adicionada ao slide que estava em foco e a galeria é substituída, de volta, pela tela principal.

O item "Tecnologias digitais de rede" possui, no momento, um único desdobramento no submenu, "ativar/desativar RSS" (item 4). A fonte dos feeds do RSS não possui interface para alteração no cliente. Atualmente, o leitor de RSS usado é o luarss, ${ }^{10}$ com algumas adaptações para integrá-lo ao software Guri.

O botão "Iniciar apresentação" inicia a apresentação a partir do primeiro slide, fazendo com que o quadro branco (área de preview do slide) seja redimensionado, a fim de ocupar toda a tela da TV, e as demais mídias também serão proporcionalmente redimensionadas. As mídias são iniciadas de forma que as imagens e textos se tornam visíveis, e os vídeos e áudios iniciam a sua execução. O botão vermelho do controle-remoto termina a apresentação e os botões direcionais alternam entre os slides. Observa-se que, ao se retornar a um mesmo slide, suas mídias serão reiniciadas a partir do início, não do ponto em que se alternou daquele slide para outro.

Por fim, o último ícone no menu principal é "Salvar apresentação", o qual salva a apresentação alterada no módulo servidor do software, permitindo a sua persistência e, portanto, que a mesma seja recuperada após a troca de canal ou o desligamento da televisão na qual se editou a apresentação por meio do cliente.

A área de preview (item 3) contém a representação do slide selecionado para edição. Imagens e textos são representados diretamente. Vídeos e áudios, no entanto, são representados por um frame capturado e por um ícone, respectivamente, uma vez que apresentá-los diretamente seria de pouca praticidade para a edição. O foco pode ser passado para a área de preview selecionando-se a tecla direcional para baixo enquanto o foco pertencer a algum item do menu principal. Uma vez que a área de preview esteja em foco, é possível alternar o slide em edição, usando-se as teclas direcionais do controle remoto para os lados.

A composição do slide (arranjo do conjunto de mídias que o compõe) é feita passando-se o fluxo de controle para área de preview. Para isso, seleciona-se a área de controle quando ela está em foco (o fluxo de controle também é transferido para a área quando uma mídia é adicionada). Feito isso, uma das representações das mídias receberá o foco e poderão ser usados os botões do controle para edição: a) o botão verde para voltar o fluxo de controle para a tela de edição, com o foco na área de preview; b) o botão vermelho para excluir a mídia em foco; c) o botão amarelo para se alternar entre as funções das teclas direcionais, quais sejam: mover o foco através das mídias, alterar a posição da mídia em foco e redimensionar a mídia em foco (estas últimas duas somente para mídias não áudio).

No que se refere ao módulo servidor, este é composto de um WebService e uma interface web, ambos desenvolvidas em Java (conforme Figura 2). Os protótipos da iteração atual de ambos os submódulos do servidor (WebService e interface web) tem como principais responsabilidades, respectivamente, a persistência das apresentações e o gerenciamento dos usuários. O WebService garante a persistência respondendo as requisições do cliente para criar novas apresentações, além de alterar, recuperar e listar as apresentações armazenadas, sempre verificando a autenticidade e a permissão do usuário a cada requisição. A interface web tem como principal objetivo oferecer ao professor um ambiente de gerenciamento dos alunos, onde é possível adicionar e excluir o cadastro desses discentes, permitindo, assim, a utilização de uma determinada apresentação de slides multimídia no módulo cliente.

\footnotetext{
${ }^{10}$ Desenvolvido por Manoel Campos, disponível em: http://manoelcampos.com/tvd/leitor-de-rss-para-tv-digital/
} 


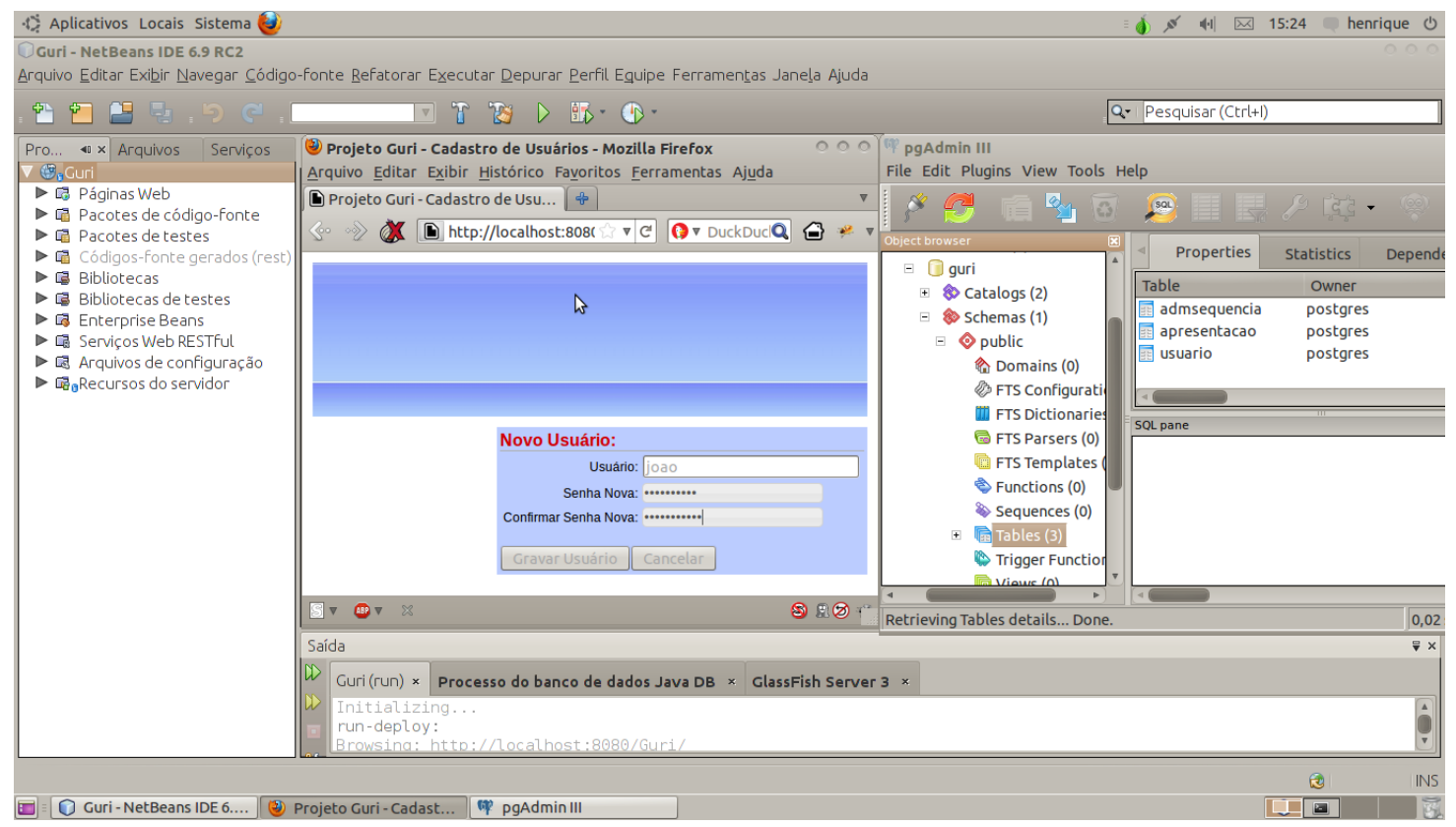

Figura 2: Tecnologias utilizadas no desenvolvimento do módulo WebService

A conexão entre os módulos cliente e servidor do software Guri deve ser feita através do canal de interatividade, que é um subsistema da arquitetura de referência do SBTVD-T, “[...] através do qual cada usuário [...] pode interagir encaminhando ou recebendo informações e solicitações das emissoras/programadoras" [7, p. 31]. Existem diversas tecnologias de redes de acesso passíveis de serem utilizadas para a comunicação de dados entre as aplicações interativas (como o módulo cliente) e os provedores de conteúdos (como o webservice do módulo servidor) no contexto do SBTVD-T, tais como a xDSL, PLC, MMDS, WiFi, WiMax, entre outras.

Assim, o canal de interatividade no SBTVD-T torna-se o subsistema responsável por efetuar a interconexão entre os sistemas de televisão e telecomunicação, sustentando as características e potencialidades da TV digital ligadas à convergência digital e à comunicação bidirecional ([14] e [7, p. 31]). Nesses termos, no âmbito do desenvolvimento do software de autoria colaborativa Guri, tanto no que se refere à parte tecnológica quanto educacional, tal subsistema constitui o elemento central que permite ocupar todo o potencial interativo da TV digital no desenvolvimento de aplicações educacionais que abram perspectivas para uma práxis pedagógica pautada pela comunicação/diálogo.

Em síntese, tomando como infraestrutura esse novo meio de comunicação, a TV digital visa, através do software Guri, oferecer um lócus tecno-educacional para que professores, alunos e demais seres sociais constituam verdadeiras redes de ensino-aprendizagem no ciberespaço [4, p. 120], ressignificando, assim, tanto as suas práticas educativas presenciais quanto virtuais. Tal tecnologia torna-se, portanto, um meio efetivo para que os processos educativos sejam repensados, visando atender esta lógica comunicacional contemporânea instaurada pelo fenômeno da cibercultura, ou seja, a da comunicação interativa. Aspira-se, por fim, que os próprios processos de ensino-aprendizagem atinjam tal patamar de comunicação/diálogo/interatividade.

\section{Considerações finais}

Através do presente artigo objetivou-se a descrição de um trabalho em desenvolvimento, a implementação de um software de autoria colaborativa denominado "Guri”, cujo objetivo consiste em proporcionar aos professores, alunos e demais entes sociais envolvidos nos processos de ensino-aprendizagem escolares a produção de materiais educativos hipermídia através da TV digital.

Ao término da implementação do protótipo em sua iteração atual, possuir-se-á um software que permite aos usuários editarem e exibirem na TV digital apresentações de slides multimidiais, além de serem capazes de salvá-las e recuperá-las em um suporte externo à sua infraestrutura televisiva, porém, ainda sem a possibilidade de as compartilhar entre si. Pretende-se, no entanto, que o software "Guri" venha agregar progressivamente as 
funcionalidades que possibilitem a autoria colaborativa de malhas hipermidiais (ao invés de apresentações multimídia) entre os usuários do sistema.

Para isso, planeja-se uma série de trabalhos futuros que visam efetuar essas melhorias, sendo as mais prementes: a) a alteração do módulo servidor para permitir que uma apresentação seja compartilhada entre dois ou mais usuários (ainda que a edição síncrona não seja permitida); b) a adição do suporte a um número maior de TDRs (como o Twitter, Wikipédia, YouTube etc.); c) a modificação do módulo cliente para que o mesmo permita a edição e visualização de uma malha hipermídia.

\section{Agradecimentos}

Ao CNPq (Conselho Nacional de Desenvolvimento Científico e Tecnológico), pelo fornecimento das bolsas de pesquisa necessárias à realização dos estudos descritos neste artigo.

\section{Referências}

[1] LEMOS, André. Cibercultura: alguns pontos para compreender a nossa época. In: LEMOS, André; CUNHA, Paulo (Org.). Olhares sobre a cibercultura. Porto Alegre: Sulina, 2003. p. 11-23.

[2] IBGE. Instituto Brasileiro de Geografia e Estatística. Pesquisa nacional por amostra de domicílio: síntese de indicadores. Rio de Janeiro: IBGE, 2010. Disponível em: $<$ http://www.ibge.gov.br/home/estatistica/populacao/trabalhoerendimento/pnad2009/pnad_sintese_2009.pdf> . Acesso em: 16 abr. 2010.

[3] BRASIL. Ministério das Comunicações. Decreto n. 5.820, de 29 de junho de 2006. Dispõe sobre a implantação do SBTVD-T. Brasília: Minicom, 2006. Disponível em: $<$ http://www.mc.gov.br/tv_digital_decreto4901_27112003.htm>. Acesso em: 18 jun. 2010.

[4] MALAGGI, Vitor. Imbricando projetos de ensino-aprendizagem e tecnologias digitais de rede: busca de resignificações e potencialidades. 2009. Dissertação (Mestrado em Educação) - Universidade de Passo Fundo, Passo Fundo, 2009.

[5] LÉVY, Pierre. A inteligência coletiva: por uma antropologia do ciberespaço. 4. ed. São Paulo: Loyola, 2003.

[6] SILVA, Marco. Sala de aula interativa. 3. ed. Rio de Janeiro: Quartet, 2002.

[7] CPQD. Arquitetura de referência: sistema brasileiro de televisão digital terrestre. 2006. Disponível em: $<$ http://www.technospice.com/files/71_141_ANEXO1_arquitetura_referencia_sbtv.pd $>$. Acesso em: 10 jan. 2010.

[8] TEIXEIRA, Adriano Canabarro. Formação docente e inclusão digital: a análise do processo de emersão tecnológica de professores. 2005. Tese (Doutorado em Informática na Educação) - Universidade Federal do Rio Grande do Sul, Porto Alegre, 2005.

[9] FREIRE, Paulo. Extensão ou comunicação? 7. ed. Rio de Janeiro: Paz e Terra, 1983.

[10] _. _ Pedagogia do oprimido. 17. ed. Rio de Janeiro: Paz e Terra, 1987.

[11] SILVA, Marco. Um convite à interatividade e à complexidade: novas perspectivas comunicacionais para a sala de aula. In: GONÇALVES, Maria Alice Rezende (Org.). Educação e cultura: pensando em cidadania. Rio de Janeiro: Quartet, 1999. p. 135-167. 
[12] BARANAUSKAS, Maria C. Calani et al. Uma taxonomia para ambientes de aprendizado baseados no computador. In: VALENTE, José Armando (Org.). O computador na sociedade do conhecimento. Brasília: MEC/SEED/ProInfo, 1999. p. 45-69. (Coleção Informática para a mudança na educação).

[13] BECK, Kent. Programação extrema (XP) explicada: acolha as mudanças. São Paulo: Bookman, 2004.

[14] STRAUBHAAR, Joseph D.; LAROSE, Robert; DUARTE, Luiz Guilherme (Rev.). Comunicação, mídia e tecnologia. São Paulo: Thomson Learning, 2004.

[15] BRASIL. Ministério das Comunicações. Minuta de exposição de motivos da TV Digital. Brasília: Minicom, 2003. Disponível em: <http://www.mc.gov.br/tv-digital/minuta-de-exposicao-de-motivos>. Acesso em: 20 jun. 2010. 